\title{
The Effect of Good Corporate Governance on Profit Management with Tax Planning as Intervening Variable on Mining Companies Listed on Indonesia Stock Exchange (2014-2018)
}

\author{
Rachma Mariana ${ }^{1}$, Muhammad Din $^{2}$, Lucyani Meldawati ${ }^{2 *}$, Muhammad Dharma \\ Halwi $^{2}$, Nimade Suwitri Parwati ${ }^{2}$, Abdul Pattawe ${ }^{2}$ \\ ${ }^{I}$ Student of Accounting Department, Tadulako University, Palu, Indonesia \\ ${ }^{2}$ Lecturer in Accounting Department, Tadulako University, Palu, Indonesia \\ *Corresponding author. Email: Im.akuntad@gmail.com
}

\begin{abstract}
This study aims to determine and analyze the influence of good corporate governance on earnings management with tax planning as intervening variable. The number of samples studied were 8 companies from a total of 47 companies which were used as the study population. The sampling was done by using purposive sampling method. The type of company used in this study is mining companies. The data used are financial reports and annual reports of mining companies for 2014-2018 (40 observations) obtained from Indonesia Stock Exchange website. The data analysis technique is by using Partial Least Square with the help of the WarpPLS version 6.0 program. The results of this study indicate that (1) the audit committee has no effect on earnings management. It means that the proportion of independent commissioners and managerial ownership has a negative effect on earnings management, while institutional ownership has a positive effect on earnings management. (2) The audit committee and the proportion of the independent board of commissioners have a negative effect on tax planning, institutional ownership has a positive effect on tax planning while managerial ownership has no effect on tax planning. (3) Tax planning has a positive effect on earnings management, and (4) tax planning mediates the relationship between the audit committee, the proportion of independent commissioners, and institutional ownership of earnings management. However, tax planning does not mediate the relationship between managerial ownership and earnings management.
\end{abstract}

Keywords: Audit Committee, Proportion of Independent Commissioners, Institutional Ownership, Managerial Ownership, Earnings Management, Tax Planning.

\section{INTRODUCTION}

The profit generated by a company is an index that can measure financial performance in terms of the success or failure of a business in terms of achieving the specified operations. Managers have the right to choose among various forms of tracking transactions and choose alternatives that occur under the same accounting treatment. This freedom, which managers can use to adapt to various economic conditions and can describe actual economic transactions, can also be used to influence earnings over time to generate benefits for management and stakeholders.

The enactment of government regulations in the Mining Law concerning the ban on exports of raw minerals which came into effect in 2014 contributed to the weakening of GDP growth in the mining sector, where many mining companies experienced a decline in revenue, and many mining companies suffered losses. 
Data from the Ministry of Finance shows that in 2016 showed that the tax ratio from the contribution of the mineral and coal mining sector was only $3.9 \%$, while the national tax ratio was $10.4 \%$ in 2016 . There were 4,532 taxpayers in the coal industry, compared to 8,003 taxpayers in 2015 which did not report the tax reports. It should also be noted that there are reports that are not in accordance with the facts on the ground among taxpayers who report their tax reports. Many also report their tax returns correctly, but they are the product of tax evasion and taxation, such as aggressive tax planning, corporate acquisitions, revenue shifts, and transfer pricing failures.

\section{LITERATURE REVIEW}

\subsection{Agency Theory}

According to the conception of earnings management, Putri [1] showed that agency theory approach informs earnings management practices due to conflicts of interest between management (agents) and owners that occur when each party tries to achieve or maintain the level of abundance. Shareholders and management have different priorities resulting a conflict of interest.

Management has data asymmetry about parties outside the company, such as investors and creditors in agency relationships. Knowledge asymmetry occurs when the owner cannot directly track the daily activities of management to ensure that management is working according to the will of the owner or there may not be sufficient information regarding the agent's performance. As agents, management has data about their abilities, work climate, and the business as a whole. Managers can manipulate earnings in financial statements to deceive shareholders about the economic capacity of the company.

\subsection{Good Corporate Governance}

The structure is made by the company which is then built as a stakeholder concern. It encourages relationships and obligations between staff, creditors and internal and external stakeholders who manage the company to achieve the desired company goals. It is structured according to the laws and regulations and had interests and paid attention to the needs of stakeholders [2].

\subsection{Profit management}

Widyaningdyah [3] defines earnings management by definition in the choice of accounting system. In this situation, it is explained in the sense that the manager's actions in deciding earnings play with the portion of discretionary accruals.
Management activities aims to increase the benefits of the unit for which the manager is responsible, as currently stated, although there is an increase or decrease in the long-term economic profitability of the unit.

Referring to Lolana and Dwimulyani [4], earnings management is measured using the modified Jones model formula:

Step 1: Calculate total accruals

$$
\begin{gathered}
T A C=\text { Net income }- \text { Cash flows from } \\
\text { operations }
\end{gathered}
$$

Step 2: The total value of accruals is estimated by regression analysis

$\frac{T A C_{i t}}{T A_{i t-1}}=a_{1}\left(\frac{1}{T A_{i t-1}}\right)+a_{2}\left(\frac{\Delta S A L_{i t}}{T A_{i t-1}}\right)+a_{3}\left(\frac{P P E_{i t}}{T A_{i t-1}}\right)+\varepsilon_{i t}$

Step 3:

$$
\begin{gathered}
N D A_{i t}=a_{1}\left(\frac{1}{T A_{i t-1}}\right)+a_{2}\left(\frac{\Delta S A L_{i t}-\Delta R E C_{i t-1}}{T A_{i t-1}}\right) \\
+a_{3}\left(\frac{P P E_{i t}}{T A_{i t-1}}\right)+\varepsilon_{i t}
\end{gathered}
$$

Step 4: Calculating discretionary accruals

$$
D A_{i t}=\frac{T A C_{i t}}{T A_{i t-1}}-N D A_{i t}
$$

\subsection{Tax Planning}

Lumbantoruan [5] defines tax administration as a tool in fulfilling tax commitments properly. But, the quantity of tax collected is as small as possible to get profits and liquidity that is in line with management expectations. Tax planning with reference to Wardani and Santi [6] is measured by the formula:

$$
T R R=\frac{\text { Net Income }_{i t}}{\text { Pretax Income }(E B I T)_{i t}}
$$

\subsection{Hypothesis}

H1: The audit committee has a negative effect on earnings management

H2: The proportion of independent Board of Commissioners has a negative effect on earnings management

H3: Institutional ownership has a positive effect on earnings management

H4: Managerial ownership has a negative effect on earnings management

H5: The audit committee has a negative effect on tax planning 
H6: The proportion of independent Board of Commissioners has a negative effect on tax planning

H7: Institutional ownership has a positive effect on tax planning

H8: Managerial ownership has a negative effect on tax planning

H9: Tax planning has a negative effect on earnings management

H10: Tax planning mediates the effect of audit on earnings management

H11: Tax planning mediates the effect of the proportion of independent commissioners on earnings management

H12: Tax planning mediates the effect of institutional ownership on earnings management

H13: Tax planning mediates the effect of managerial ownership on earnings management

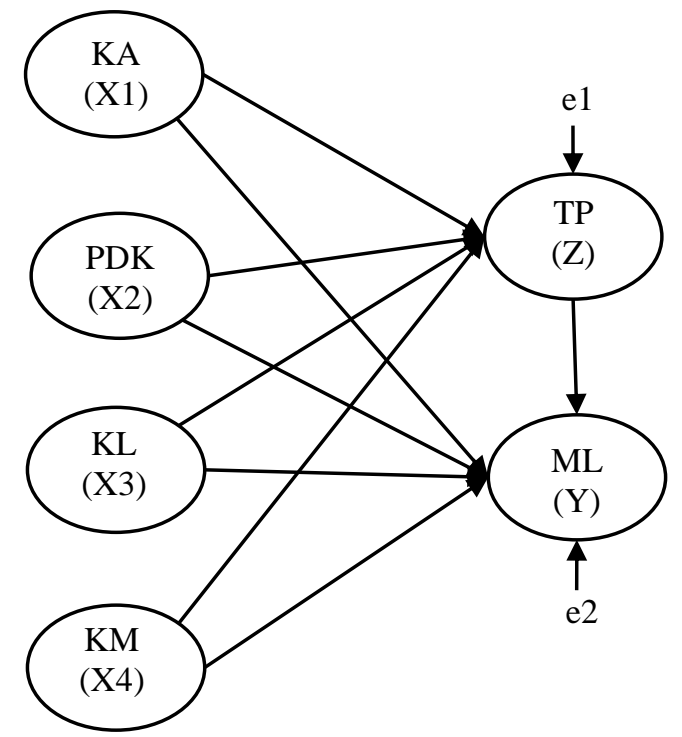

Figure 1 Conceptual Framework

\section{RESEARCH METHOD}

The object of this research is good corporate governance, namely variable $\mathrm{X}$ (earnings management) and variable $\mathrm{Y}$ (tax planning) (Figure 1). It researched mining companies listed on the Indonesia Stock Exchange with the observation year 2014-2018. The methodology used is the verification process, which is an analysis that uses the presentation of the results of ideas. The type of data is secondary data, which is obtained from the 2014-2018 financial statements on the IDX official website (www.idx.com) and the company's official website.

The data in this study were processed using quantitative methods with approaches or with the help of PLS (Partial Least Square). PLS was chosen because in the theoretical framework model and the research model that was built, it described the existence of mediating/intervening variables [7].

\section{RESULTS AND DISCUSSION}

The Structural Model Evaluation Results (Inner Model) was conducted with evaluating Coefficient of Determination Test $\left(\mathrm{R}^{2}\right)$.

Table 1. R-Squared Value

\begin{tabular}{|l|c|}
\hline \multicolumn{1}{|c|}{ Variable } & R-Squared \\
\hline Tax Planning & 0.513 \\
\hline Profit management & 0.262 \\
\hline
\end{tabular}

Source: WarpPLS 6.0, data processed (2021)

Table 1 showed the results of the coefficient of determination (R2) obtaining the $\mathrm{R}^{2}$ value for the tax planning variable of 0.513 . Meanwhile, the $\mathrm{R}^{2}$ value obtained by the earnings management variable is 0.262 which means that the earnings management variance can be explained by $26.2 \%$ by the audit committee, the proportion of the board of commissioners, institutional ownership, and managerial ownership. So, it can be concluded that the research model is included in the moderate criteria. Tthis is rated from the value of $\mathrm{R}^{2} \leq 0.45$.

The results of the effect size contained in the output standard errors and effect size for path coefficient can be seen in Table 2.

Table 2. Effect Size for Path Coefficient Value \begin{tabular}{l|l|l|} 
Variable Relationship & Effect Size (f2) & Category \\
\hline
\end{tabular}

\begin{tabular}{|c|c|c|}
\hline$X 1 \rightarrow Y$ & 0.016 & Low \\
\hline$X 2 \rightarrow Y$ & 0.010 & Low \\
\hline$X 3 \rightarrow Y$ & 0.110 & Moderate \\
\hline$X 4 \rightarrow Y$ & 0.028 & Moderate \\
\hline$X 1 \rightarrow Z$ & 0.175 & Moderate \\
\hline$X 2 \rightarrow Z$ & 0.001 & Low \\
\hline$X 3 \rightarrow Z$ & 0.354 & High \\
\hline$X 4 \rightarrow Z$ & 0.016 & Low \\
\hline$Z \rightarrow Y$ & 0.098 & Moderate \\
\hline
\end{tabular}

Source: WarpPLS 6.0, data processed (2021)

Based on the results of the effect size (f2) in Table 2 , it shows that the effect size of the audit committee and the proportion of independent commissioners on earnings management is included in the low category. Likewise, it occurs with the proportion of independent commissioners and managerial ownership of taxes. However, the estimation results of institutional ownership and managerial ownership on earnings 
management show a medium effect size value. Likewise, it is also occured with the audit committee on tax planning and tax planning on earnings management. Meanwhile, the results of the estimation of institutional ownership on tax planning show a high effect size value.

To examine Predictive Validity Test $\left(\mathrm{Q}^{2}\right)$, based on the results of data processing using WarpPLS 6.0, the Q2 value is obtained as shown in Table 3 .

Table 3. Q-Squared Value

\begin{tabular}{|l|c|}
\hline \multicolumn{1}{|c|}{ Variable } & Q-Squared \\
\hline Tax Planning & 0.515 \\
\hline Profit management & 0.290 \\
\hline
\end{tabular}

Source: WarpPLS 6.0, data processed (2021)

The results of the predictive validity test show that the Q-Squared value is greater than zero (0), namely 0.515 for the tax planning construct and 0.290 for the earnings management construct. So, it can be concluded that the research model has a good predictive validity.

To assess the fit model, it can be determined by several fit indicators with the results can be seen in Table 4.

Table 4. Fit Model Test Results

\begin{tabular}{|c|}
\hline Model fit and quality indices \\
\hline Average path coefficient $(A P C)=0.290, P<0.001$ \\
\hline Average $\mathrm{R}$-squared $(\mathrm{ARS})=0.387, \mathrm{P}<0.001$ \\
\hline Average adjusted $\mathrm{R}$-squared (AARS) $=0.249, \mathrm{P}<0.001$ \\
\hline $\begin{array}{l}\text { Average block VIF }(\text { AVIF })=1.760 \text {, acceptable if }<=5 \text {, } \\
\text { ideally }<=3.3\end{array}$ \\
\hline $\begin{array}{l}\text { Average full collinearity VIF } \quad(\text { AFVIF })=1.914 \text {, } \\
\text { acceptable if }<=5 \text {, ideally }<=3.3\end{array}$ \\
\hline $\begin{array}{l}\text { Tenenhaus GoF }(\mathrm{GoF})=0.622, \text { Small } \geq 0,1, \text { medium } \geq \\
0,25, \text { large } \geq 0,36\end{array}$ \\
\hline
\end{tabular}

Source: WarpPLS 6.0, data processed (2021)

Table 4 showed the estimated value generated based on the size index of the fit model. It can be concluded that the overall research model has a good fit and is considered feasible, where the P-value for APC, ARS, and AARS $<0.05$ with the APC index = $0.290, \mathrm{ARS}=0.387$, and AARS $=0.249$. Likewise, the resulting AVIF and AFVIF indices have the value $<3.3$, which means that there is no multicollinearity problem between indicators and between exogenous variables.

Next, the test performs the hypothesis testing results. The first hypothesis states that the audit committee (X1) has an insignificant negative effect on earnings management $(\mathrm{Y})$. The test results on the parameters between the audit committee and earnings management as shown in the output of the structural equation model in Figure 2 show that there is no influence between the two variables. The resulting path coefficient value is -0.08 with a significant value of $p=0.20(>0.10)$. Thus, the first hypothesis is rejected. The results of this study are in line with research by Taco and Ilat [8] which state that the audit committee has no effect on earnings management.

The second hypothesis states that the proportion of the board of commissioners (X2) has a negative and significant effect on earnings management $(\mathrm{Y})$. The path coefficient value generated in the influence of the proportion of independent commissioners on earnings management is -0.12 with a significant value of $p=0.10 \quad(<0.10)$. Thus, the second hypothesis is accepted.

The third hypothesis states that institutional ownership (X3) has a positive effect on earnings management (Y). The resulting path coefficient value in the influence of institutional ownership on earnings management is 0.39 with a significant value of $p<.01$ $(<0.10)$. Thus, the third hypothesis is rejected.

The fourth hypothesis states that managerial ownership (X4) has a negative effect on earnings management $(\mathrm{Y})$. The resulting path coefficient value is -0.33 with a significant value of $p<.01 \quad(<0.10)$. Thus, the fourth hypothesis is accepted. Increasing managerial ownership will encourage managers to improve their performance, which will have a good influence on the company and help shareholders achieve their goals.

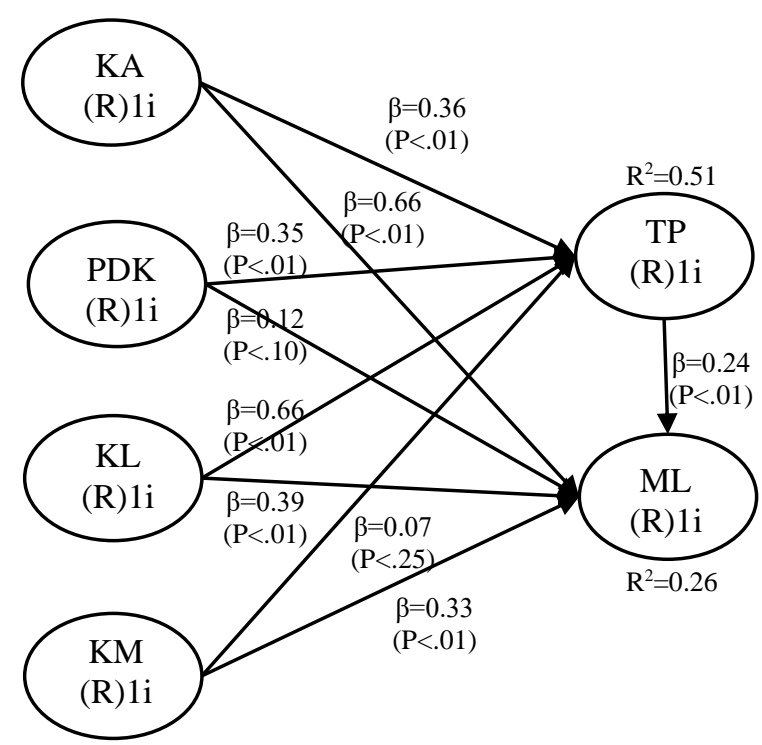

Figure 2 Research Results Model

Source: WarpPLS 6.0, data processed (2021)

The fifth hypothesis states that the audit committee (X1) has a negative effect on tax planning (Z). The 
path coefficient value generated in the influence of the audit committee on tax planning is -0.36 with a significant value of $p<.01 \quad(<0.10)$. Thus, the fifth hypothesis is accepted.

The sixth hypothesis states that the proportion of independent commissioners (X2) has a negative effect on tax planning $(\mathrm{Z})$. The resulting path coefficient value is -0.35 with a significant value of $p<.01$ $(<0.10)$. Thus, the sixth hypothesis is accepted. This is in accordance with the findings of Putri [1] who found that good corporate governance as measured by institutional ownership has a significant influence on tax planning.

The seventh hypothesis states that institutional ownership (X3) has a positive effect on tax planning (Z). The resulting path coefficient value in the influence of institutional ownership on tax planning is 0.66 with a significant value of $p<.01(<0.10)$. Thus, the seventh hypothesis is rejected. I

The eighth hypothesis states that managerial ownership (X4) has an insignificant negative effect on tax planning $(\mathrm{Z})$. The resulting path coefficient value in the influence of managerial ownership on tax planning is -0.07 with a significant value of $p=0.25$ (>0.10). Thus, the eighth hypothesis is rejected.

The ninth hypothesis states that tax planning $(\mathrm{Z})$ has a positive and significant effect on earnings management (Y). The path coefficient value generated in the effect of tax planning on earnings management is 0.24 with a significant value of $p<.01(<0.10)$. Thus, the ninth hypothesis is accepted. This is in line with the research by Erawati and Lestari [9] which states that tax planning has a positive effect on earnings management [10].

Moreover, mediation test results were performed with direct and indirect effect tests. The estimation results of the direct effect can be seen in Figure 3, Figure 4.

After testing the mediation, the results of the correlation between the audit committee (X1) and earnings management $(\mathrm{Y})$ showed a path coefficient value of -0.08 and a significant value of $p=0.20$. Meanwhile, the direct effect model showed the correlation between the audit committee (X1) and earnings management $(\mathrm{Y})$ shows the path coefficient value of -0.19 and the significant value of $p=0.03$. The result of the correlation between the proportion of independent commissioners (X2) on earnings management $(\mathrm{Y})$ shows a path coefficient value of 0.12 and a significant value of $p=0.10$. Meanwhile, the direct effect model the correlation results between the proportion of independent commissioners (X2) on earnings management $(\mathrm{Y})$ shows a path coefficient value of -0.38 and a significant value of $p<.01$. The results of the correlation between institutional ownership (X3) and earnings management (Y) show a path coefficient value of 0.39 and a significance of $\mathrm{P}<.01$, while in the direct effect model the correlation between institutional ownership (X3) and earnings management $(\mathrm{Y})$ shows a path coefficient value. of 0.56 and a significant value of $p<.01$. The results of the correlation between managerial ownership (X4) and earnings management (Y) show a path coefficient value of -0.33 and a significant value of $p<.01$, while the direct effect model the correlation between managerial ownership (X4) and earnings management (Y) shows a coefficient path of -0.23 and $p$-value $=$ 0.01 .

Referring to the decision-making guidelines on mediation, it is concluded that the mediation for the audit committee on earnings management is in full mediation. Moreover, the mediation for the proportion of independent commissioners to earnings management is in the form of partial mediation. Likewise, the mediation for institutional ownership on earnings management is in the form of partial mediation. Meanwhile, managerial ownership of earnings management is not mediated by tax planning. This is because the value of the coefficient c" is increasing.

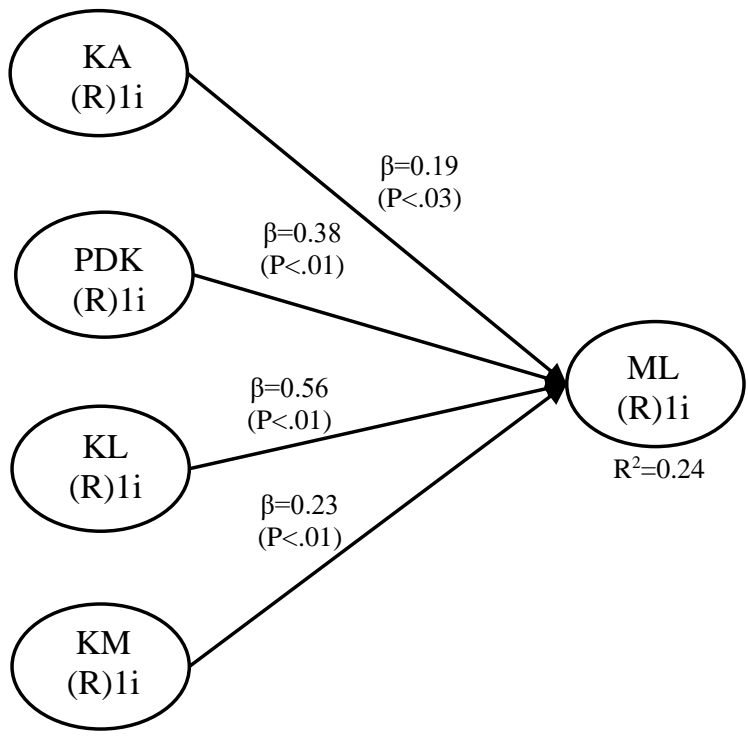

Figure 3 Output Direct Effects

Source: WarpPLS 6.0, data processed (2021) 


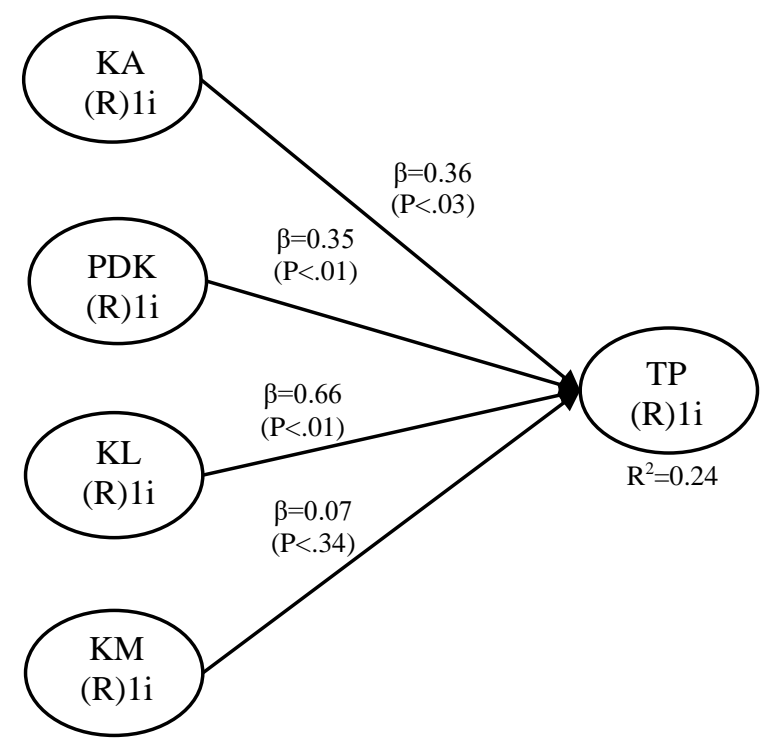

Figure 4 Output Direct Effects

Source: WarpPLS 6.0, data processed (2021)

Furthermore, the estimation results of the indirect effect can be seen in Figure 5.

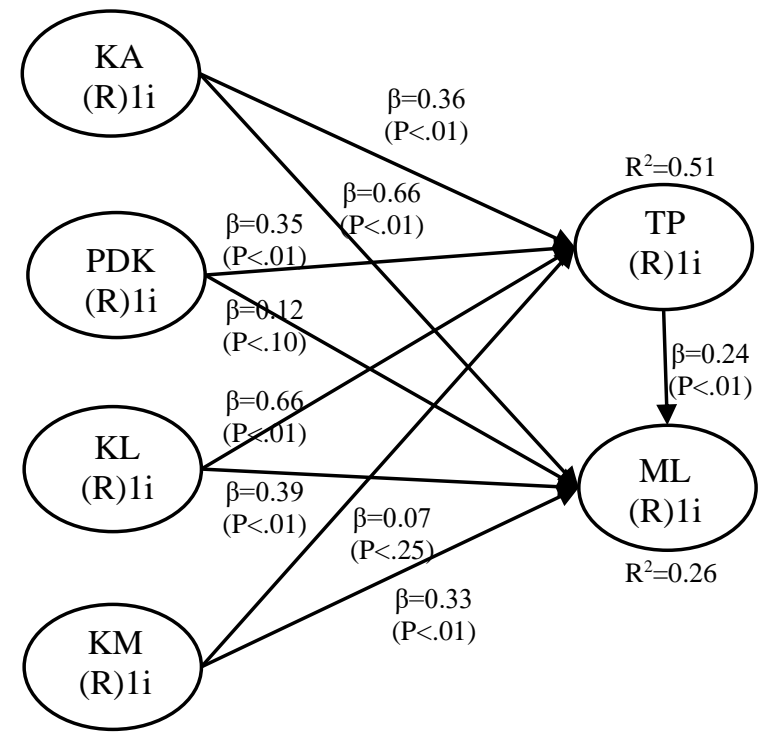

Figure 5 Output Indirect Effect

Source: WarpPLS 6.0, data processed (2021)

\section{CONCLUSION}

The results showed that audit committee and the proportion of independent commissioners have a negative effect on earnings management, while institutional ownership has a positive effect on earnings management. Furthermore, managerial ownership has no effect on earnings management. The audit committee and the proportion of independent commissioners have a negative effect on tax planning, while institutional ownership has a positive effect on tax planning and managerial ownership has no effect on tax planning.

Tax planning has a positive effect on earnings management. It mediates the effect of the audit committee, the proportion of independent commissioners and institutional ownership on earnings management. Meanwhile, tax planning cannot mediate the effect of managerial ownership on earnings management.

The limitation of this study is that some respondents were being received external assignments or were not in place, so that some questionnaires were returned late, and some did not even return. Future research is recommended to use proxies for inconsistent variables, such as good corporate governance using the size of the board of commissioners, and using different types or sectors of companies.

\section{AUTHORS' CONTRIBUTIONS}

First Author: writing, data analysis and field research; Second and third authors: method, data analysis; Fourth, fifth and sixth authors: validation.

\section{ACKNOWLEDGMENTS}

Thanks to Tadulako University for providing research and financial support, and to the conference committee for providing the opportunity to present this article.

\section{REFERENCES}

[1] D. P. Putri, Pengaruh Struktur Kepemilikan, Good Corporate Governance Dan Kebijakan Dividen Terhadap Nilai Perusahaan. Surabaya: Stiesia Surabaya, 2016.

[2] FCGI, "Peranan Dewan Komisaris dan Komite Audit dalam Pelaksanaan Corporate Governance (Tata Kelola Perusahaan)," 2nd ed., Jakarta: FCGI, 2002.

[3] A. U. Widyaningdyah, "Analisis faktor-faktor yang berpengaruh terhadap earnings management pada perusahaan go public di Indonesia," J. Akunt. dan Keuang., vol. 3, no. 2, 2001, pp. 89-101.

[4] F. L. Lolana and S. Dwimulyani, "Pengaruh Good Corporate Governance Terhadap Manajemen Laba Dengan Tax Avoidance Sebagai Variabel Intervening," in Prosiding Seminar Nasional Pakar, 2019, pp. 2-49.

[5] S. Lumbantoruan, Akuntansi Pajak. Jakarta: Gramedia Widiasarana, 1996. 
[6] D. K. Santi and D. K. Wardani, "Pengaruh tax planning, ukuran perusahaan, corporate social responsibility (csr) terhadap manajemen laba," J. Akunt., vol. 6, no. 1, 2018, pp. 11-24.

[7] I. Ghozali, Structural Equation Modeling metode Alternatif dengan Partial Least Square (PLS). Semarang: Badan Penerbit Undip, 2011.

[8] C. Taco and V. Ilat, "Effect of Earning Power, Independent Commissioner, Board of Directors, Audit Committee and Company Size of Profit Management in Manufacturing Companies Listed on the Indonesia Stock Exchange," EMBA J., vol. 4, no. 4, 2016, pp. 873-884.

[9] T. Erawati and N. A. Lestari, "Pengaruh Perencanaan Pajak (Tax Planning), Kualitas Audit Dan Kepemilikan Institusional Terhadap Manajemen Laba (Studi Empiris Pada Perusahaan Manufaktur Yang Terdaftar di Bursa Efek Indonesia Tahun 2013-2017)," J. Akunt., vol. 7, no. 1, 2019, pp. 98-111.

[10] D. Purnamasari, A. Almira, and N. Savira, "The Accounting for Inventory from a Commercial Point of View," Res. Horiz., vol. 1, no. 2, 2021, pp. 81-85. 